\title{
Revisiting the Conceptualisation of e-Campaigning: Putting Campaign Back in e-Campaigning Research
}

\author{
Hugo Gong, Miriam Lips, and Mary Tate \\ Victoria University of Wellington, Wellington, New Zealand \\ \{hugo.gong, miriam. lips, mary. tate\}@vuw.ac.nz
}

\begin{abstract}
As political parties' and candidates' e-Campaigning has become increasingly complex and sophisticated, scholars accordingly devise conceptual frameworks to understand and describe this social phenomenon. Yet, there is little scholarly debate concerning the varying conceptualisations of political parties' or candidates' utilisation of e-Campaigning. A review of existing eCampaigning conceptualisations reveals three major limitations: namely, lack of academic rigour, a technologically deterministic orientation of eCampaigning practices, and variation in the coverage of e-Campaigning practices. Potentially, these limitations might impede the comparability of eCampaigning studies over time and across countries. In response, this research paper proposes a conceptual, practice-based framework that builds on the existing research. This paper then uses empirical data from a New Zealand political party to illustrate the application of the proposed framework.
\end{abstract}

Keywords: e-Campaigning, election campaigning, conceptualisation, e-Campaigning practices, framework.

\section{Introduction}

Political election campaigning is a long-standing ritual practised by campaign teams representing political parties or candidates during an election period in an effort to garner votes and hold political offices [1], and also the research focus of electoral politics.

Within the realm of election campaigning, an emergent, global phenomenon can be observed that sees the Internet and its related applications being utilised for election campaigning. This phenomenon illuminates a new research avenue in electoral politics and is commonly referred to as $e$-Campaigning in academic literature $[2,3]$.

Since its inception, e-Campaigning has attracted scholarly interest, including a number of e-Campaigning research frameworks, and analyses of political parties or candidates' e-Campaigning practices [e.g. 2-4]. Typically, these studies have been based on a bottom-up study of the occurrence or frequency of using specific technology-enabled content elements, for example the use of social media or blogs on campaign websites. Those elements are then grouped into higher-level categories such as information dissemination $[2,5,6]$, interaction $[2,3,6]$, or targeting $[6,7]$ by the authors. However, divergent, incommensurable categories have been proposed by different scholars, and although academic research in this area is at an early stage, it is 
already difficult to compare and contrast different scholarly studies, or to combine studies in a meta-analysis. We propose to address this issue using a conceptual, practice-based framework informed by studies on campaign practices.

Political campaigning lends itself to practice-based theorising $[4,8]$. A practicebased framework focuses on our understanding of campaign practices, which predate the advent of electronic commerce, and how new technologies are appropriated to enable these; effectively, we want to put the campaign back in e-Campaigning. Although campaign practices can change over time, and may be influenced by the emergence of new technologies or applications, overall, campaign practices change much more slowly than the technologies and media used to enact them. They therefore potentially provide a stable and extensible basis for theorising about eCampaigning. Accordingly, our research question is: How can political parties' or candidates' e-Campaigning utilisation be conceptualised in a way that leverages existing understanding of campaign practices and is consistent and extensible?

The remainder of this paper is organised as follows: first, we investigate current conceptualisations of e-Campaigning utilisation and their related issues; then, we propose and discuss our conceptualisation; following that, we illustrate the application of the proposed conceptualisation with an empirical example; and last, we provide our concluding remarks.

\section{Conceptualisations of e-Campaigning Utilisation in the Literature}

e-Campaigning first emerged as a mere information kiosk in cyberspace. However, as political parties and candidates continuously engage in e-Campaigning utilisation, it has become increasingly professionalised, sophisticated and complex $[9,10]$. Since each campaign is unique and discrete, and technology is constantly evolving, the changing landscape of e-Campaigning utilisation is compared to the aphorism that one never can step into the same river twice [11].

As such, scholars often devise conceptual frameworks, commonly with a practicebased approach, to explore and understand the e-Campaigning phenomenon [8]. A practice-based approach to theorising translates a series of practices observable in a social phenomenon into contemporary theory. Supporting or enabling tools, such as those offered by ICTs, are introduced and used within those practices [8]. In the context of e-Campaigning, political parties' and candidates' practices are operationalised in a compendium of e-content elements on their e-Campaigning websites; that is, the e-content elements are manifestations of e-Campaigning practices [8]. We posit a practice-based framework that focuses on campaign practices exhibited by e-content elements. To sum up, e-Campaigning utilisation entails at least one e-Campaigning practice and each practice can be observed by one or more e-content elements.

While a practice-based approach is deemed appropriate for theorising the eCampaigning phenomenon, three main issues surfaced from a comparison of the varying theoretical frameworks in the literature: lack of academic rigour in conceptualising and theorising e-Campaigning utilisation, a technologically deterministic orientation of e-Campaigning practices, and variation in the coverage of e-Campaigning practices in existing frameworks. 
Lack of academic rigour. A scientific theory about an observable phenomenon - be it derived from another theory, a confirmed hypothesis or an empirical observation must include the constructs within the phenomenon and the relationship between the constructs, so that the theory can be falsifiable or enables understanding about the phenomenon under study [12]. Under that principle, in order to theorise the eCampaigning phenomenon, both the key constructs and the relationship between the constructs need to be articulated. Most existing theoretical frameworks of eCampaigning utilisation have clearly stated the key constructs concerning eCampaigning utilisation: namely e-content elements, e-Campaigning practices, and election campaigning; they also explain the relationship between e-content elements and e-Campaigning practices. However, hardly any of these theoretical frameworks articulates the relationship between specific e-Campaigning practices and election campaigning [e.g. 2-4, 13]; in other words, it is unclear what rational purpose each eCampaigning practice serves in relation to election campaigning. The missing explanation between e-Campaigning practices and campaigning is a major weakness in existing conceptualisations of e-Campaigning utilisation.

A technologically deterministic orientation of e-Campaigning practices. In some theoretical frameworks e-Campaigning practices are classified in accordance with the latest technologies or applications, such as RSS feeds, interactive opinion polls, and podcasts [e.g. 13, 14]. This particular orientation demonstrates a technological deterministic viewpoint of the scholars concerned: the assumption that it is the technology that drives the utilisation of e-Campaigning. We would argue that it is the wider election campaign and its associated practices that shape the utilisation of eCampaigning. This view is more closely aligned with the research orientation of scholars such as $[10,15]$. It is worth noting that our perspective does not diminish the involvement of technologies in e-Campaigning but acknowledges their enabling role with regard to e-content elements that are manifestations of campaign practices.

Variation in the coverage of e-Campaigning practices. Some scholars focus on only one e-Campaigning practice [e.g. 16, 17], whereas others cover a wide array of e-Campaigning practices [e.g. 5, 6, 18]. A possible explanation for this variation is that many studies have constructed their frameworks on the basis of a single election. Since the nature of e-Campaigning is evolutionary and contextual, it is likely that changes will happen to e-Campaigning adoption and utilisation within a specific institutional context, as well as across time [10]. Further, e-Campaigning studies in countries where ICT adoption is relatively advanced, tend to have a broader coverage of e-Campaigning practices compared to studies in countries with low levels of ICT adoption and utilisation. Generally, with the focus on a single election, many eCampaigning studies have limited themselves to ICT-supported campaign practices in that particular campaign.

\section{Towards a Conceptual Framework of e-Campaigning Utilisation}

Given the issues associated with existing frameworks, we propose a conceptual framework for better exploring and understanding e-Campaigning utilisation. 
The underlying approach of the conceptual framework proposed in this paper follows the basic principle underpinning most frameworks, namely, the inclusion of two interrelated components: e-Campaigning practices and their associated e-content elements. An extensive academic literature review was used to identify e-content elements, e-Campaigning practices, and their relationship. Before discussing the framework in depth, we explore the link between the e-Campaigning practice and election campaigning in order to solidify the theoretical foundations of the framework.

Some scholars warn that it is paramount for organisations to practice technological realism; that is, technologies per se rarely yield miracles or a competitive edge, and therefore organisations should hold a realistic view and focus on organisational practices [19]. We agree that technological realism should also be fostered in academic research of ICT-related social phenomenon. In this light, this paper posits that it is the wider campaign practices that shape the utilisation of technologies. Consequently, the e-Campaigning practices in the proposed framework are related to wider election campaign practices.

The e-Campaigning practices in our framework are derived from a review of eCampaigning in multiple elections across countries, as opposed to the common single election focus in existing frameworks. This provides a solid empirical base for the proposed framework. The framework includes the following five campaign practices: information dissemination [2, 4, 5]; voter interaction/engagement [6, 18]; support mobilisation [2, 4, 20]; targeting campaigns [6, 7]; and resource generation [5, 21, 22]. Each of these campaign practices will be further discussed below.

\subsection{Information Dissemination}

Information dissemination is considered the most fundamental, long-standing practice of election campaigning for two reasons [9].

First, election campaigns ultimately aim to influence voters' decision-making process and, with that, try to achieve votes maximisation. Information about political parties or candidates plays a critical role in this decision-making process. As Zaller explains, "every opinion is a marriage of information and predisposition: information to form a mental picture of the given issue, and predisposition to motivate some conclusion about it" [1]. This is confirmed by empirical research, which suggests that voting behaviour is strongly affected by the awareness and knowledge of political parties or candidates, formed by the availability and quality of information about political parties or candidates from sources such as election campaigns [23]. Consequently, in order to shape voters' awareness, opinions, knowledge, and, most importantly, their decision, campaign teams benefit from producing, disseminating, and reinforcing information in a timely fashion. Moreover, research shows that swing voters are most responsive to campaign information: clearly, they are the voters whom most campaign teams endeavour to woo throughout an election period [24].

Second, voters' active political involvement is crucial to election campaigning [10]. However, research from countries around the world demonstrates that voters' political involvement has declined for various reasons [10]. Thus, generating voters' interest to be involved election campaigning has been a major issue for a campaign team. Scholars point out that campaign information serves as an important stimulus for voters' political involvement. That is, the greater amount of campaign information being disseminated, the more stimulated voters could become to get involved in campaign activities [10]. 
Generally, the campaign practice of information dissemination is undertaken through a one-way, top-down approach - from campaign teams to voters. That is, no feedback or information from voters is expected [1]. This important characteristic distinguishes information dissemination from another campaign practice, namely voter interaction/engagement.

\section{E-content elements describing the operationalisation of information dissemination.}

The following e-content elements are commonly associated with information dissemination: 1. the political party's or candidate's information, such as the history of the party or candidate, ideology and values that the party or candidate stands for, and key personnel of the party; 2. candidate biographies, such as background details and the constituency of political candidates; 3 . an archive of press releases; 4. a collection of key policies; 5 . a list of the campaign news; 6 . a full coverage of campaign events; 7 . an series of campaign speeches; 8 . contact information of the party office, party leader and party candidates; or 9. information about the party's or candidate's other online presences, if there are any $[2,4,6,8,18]$.

In general, the practice of information dissemination is considered highly standardised, due to its long existence. However, technological advancement enables campaign teams to innovate the dissemination of campaign information in order to generate and sustain voters' interest. For instance, many political parties or candidates utilise Internet multimedia technology to disseminate information in text, images, sound, video, or in combination [2, 6]. Also, political parties or candidates disseminate campaign information through their campaign blogs, which in essence are online journal entries [18].

\subsection{Voter Interaction/Engagement}

This practice is also referred to as voter involvement [25]. Its underpinning rationale consists of two explanations: 1. interact with voters for campaign feedback, and 2 . engage voters for building trust and relationships.

The first explanation argues that voters' constant feedback on an election campaign is critical for campaign team to evaluates the impact of the campaign on voters. Feedback provides the campaign team with an opportunity to take necessary actions to enhance or rectify its campaign practices in a timely manner [1]. The second explanation holds that voters, especially swing voters, are more likely to cast their votes to the political party or candidate whom they trust or feel more closely connected with [26]. Often, trust and connectedness are developed as a result of continuous efforts by a political party or candidate to interact and engage with voters. Furthermore, trust and connectedness are considered as taking precedence over securing, sustaining and mobilising grassroots support [8].

E-content elements describing the operationalisation of voter interaction/ engagement. Offline interaction and engagement can be categorised in two forms: synchronous and asynchronous [27]. The former refers to real time interaction, such as face-to-face communication; the latter denotes delayed interaction, such as postal mail. Those forms of interaction and engagement can be simulated online.

Synchronous voter interaction/engagement can be observed in: 1. instant chat/messaging; 2 . instant opinion polls that are initiated by either the campaign team or voters; 3 . instant surveys; or 4. applications that allow voters to interact with the 
political party's or candidate's key policies - such as tax/debt calculator - or campaign events - such as interactive events calendar, in real time [5, 6, 13, 14, 18].

Asynchronous voter interaction/engagement in e-Campaigning is reflected in: 1 . means to contact the political party or candidate, such as email or web form; 2 . discussion forums; 3 . interactive campaign blogs - blogs that enable readers to leave feedback or comments, in contrast to those disabling readers feedback or comments and thus considered as a form of information dissemination; or 4. means for voters to provide feedback about political party's or candidate's policies $[6,13,14,18]$.

\subsection{Support Mobilisation}

This practice represents the mobilisation theory [8]. It suggests that political parties' or candidates' effort to maximise their votes/seats is reliant upon voters' support. Such support is reflected in different forms, such as organising and participating in campaign events - for example political rallies, and, most importantly, casting vote to the political party or candidate on election day. In this light, it is vital for campaign teams to identify potential supporters and translate support sentiment from them and the existing faithful into tangible support actions [8].

Support mobilisation has been frequently regarded by campaign teams and scholars as an ever-increasing challenge [22]. Voters not only have taken a back seat but also spend less time to participate in events supporting their party or candidate [20]. A further assault to this challenge is political disengagement of young voters who are below the age of 30. Those young voters represent the fastest growing voting population; they are the least likely to vote on election day and also account for the largest group of voters who are least interested in conventional politics [22]. Given an increasing number of people, particularly the youth, connected to the Internet across the globe, it is anticipated that e-Campaigning can shed light on alleviating the severe challenges in campaign teams' practice of support mobilisation.

E-content elements describing the operationalisation of support mobilisation. In e-Campaigning, political parties' or candidates' support mobilisation is generally operationalised through providing: 1 . means to invite supporters' friends and relatives to participate in campaign events organised by the parties or candidates; 2 . means to inform voters of electoral information, such as voter registration, election date and voting location; 3 . means to receive campaign information and updates; 4 . links to supporter groups that are either formed by the parties or candidates, or by supporters themselves; 5. means to download campaign materials; or 6. means to forward campaign materials to others $[2,6,20]$.

\subsection{Targeting Campaigns}

As a campaign practice, targeting campaigns in general encompasses two distinct forms. The first is reflected in political parties' or candidates' election campaigns targeting their political rivals in the same election; it can be the rivals' specific views, policies, or the rivals in general. The fundamental assumption is that in order to sway voters' opinions and decision, a political party or candidate can devise an alternative practice to information dissemination, which aims at persuading and converting voters, especially swing voters, through "painting the public perception of the 
political party or candidate in a more favourable light" by launching attacks on its political opponents or their policies [1].

The second form of targeting campaigns pertains to election campaigns that target specific voter strata. Its underlying discourse, narrowcasting, suggests that the needs and wants across voter strata vastly differ. Hence, effective campaigns depend upon not only increasing information being disseminated, but, more importantly, disseminating the right information to the right addresses [7, 10]. In contrast to information dissemination that fosters mass communication and assumes that the characteristics of all voters are homogeneous, this form of practice emphasises tailored campaign information based on the unique characteristics of each voter stratum. Due to its nature, campaigns targeting specific voter strata require the precise voter segmentation.

Although the two forms of targeting campaigns differ fundamentally in their strategic aims, they both emphasise targeting a specific subject - be it a political rival or voter stratum - in order to achieve the ultimate purpose of election campaigning.

E-content elements describing the operationalisation of targeting campaigns. The operationalisation of e-Campaigns targeting political rivals could be observed in online contents such as speeches or press releases, which specifically aim at attacking political rivals' policies or the rivals in general [25].

Political parties or candidates' e-Campaigns targeting particular voter strata is reflected in contents dedicated to a specific voter segment or an individual visitor [7].

\subsection{Resource Generation}

To political parties and candidates in general, election campaigning is acutely dependent upon scarce resources [28].

Specifically, human resources are highly required in order for campaign teams to plan, organise and conduct different campaign activities. Ever since the practice of electioneering entered the era of modernism - characterised by television becoming the predominant technological platform for election campaigning - campaign advertising on television has become the norm in many democracies [1]. That, among other campaigning activities, often consumes the largest share of political parties' or candidates' financial resources. In addition to televised campaign advertising, political parties or candidates need to finance other electioneering activities, such as direct mailing, in-person engagement with voters, telephone and door-to-door canvassing [1].

Given the intense reliance on resources, it is essential for political parties or candidates to establish a solid practice in election campaigning to solicit resources of different forms. Resource generation is not directly associated with influencing voting decision; it, however, affects the sustainability and continuity of political parties' or candidates' election campaigning in general. The practice of resource generation in traditional election campaigning is often reflected in recruitment of members or volunteers, and different forms of fund raising.

E-content elements describing the operationalisation of resource generation. Resource generation in e-Campaigning is largely similar to that in traditional offline campaigning. Specifically, it involves establishing: 1. means to make online donations, such as online credit card payment; 2. merchandise shop; 3 . means to become a party member; or 4 . means to become a volunteer $[5,6,20]$. 


\subsection{Summary}

In this section we propose and describe a conceptual framework of e-Campaigning utilisation. Figure 1 encapsulates our conceptualisation and represents the framework proposed in this study.

\begin{tabular}{|c|c|}
\hline e-Campaigning practice & e-Content elements \\
\hline \multirow{10}{*}{ Information dissemination } & Political party's or candidate's information \\
\hline & Candidate biography \\
\hline & Press releases \\
\hline & Policy statements \\
\hline & Campaign news \\
\hline & Campaign events \\
\hline & Speeches \\
\hline & Contact information \\
\hline & $\begin{array}{l}\text { Information about the political party's or candidate's other } \\
\text { online presences }\end{array}$ \\
\hline & Campaign blogs without visitor comments allowed \\
\hline \multirow{9}{*}{ Voter interaction/engagement } & Instant chat/messaging \\
\hline & Instant opinion polls \\
\hline & Instant surveys \\
\hline & $\begin{array}{l}\text { Applications for interacting with the political party's or } \\
\text { candidate's policies }\end{array}$ \\
\hline & Interactive calendar of campaign events \\
\hline & Means to contact the political party or candidate \\
\hline & Discussion forums \\
\hline & Campaign blogs with visitor comments allowed \\
\hline & Means to provide feedback \\
\hline \multirow{6}{*}{ Support mobilisation } & $\begin{array}{l}\text { Means for voters to invite their peers to participate in } \\
\text { campaign events }\end{array}$ \\
\hline & Means to inform voters of electoral information \\
\hline & $\begin{array}{l}\text { Means for voters to receive campaign information and } \\
\text { updates }\end{array}$ \\
\hline & Means for voters to connect with supporter groups \\
\hline & Means for voters to download campaign materials \\
\hline & Means for voters to forward campaign materials to others \\
\hline \multirow{3}{*}{ Targeting campaigns } & Contents targeting political opponents \\
\hline & Contents targeting political opponents' policies \\
\hline & Contents targeting specific voter strata \\
\hline \multirow{4}{*}{ Resource generation } & Means to make donations \\
\hline & Merchandise shop \\
\hline & Means to become a party member \\
\hline & Means to become a volunteer \\
\hline
\end{tabular}

Fig. 1. The Conceptual Framework Proposed in This Study 


\section{Applying the Conceptual Framework: An Empirical Example}

We use a New Zealand political party National's 2011 e-Campaign home page, as depicted in Figure 2, as an empirical example to illustrate the application of the conceptual framework proposed in this study.

National's e-Campaign is content rich, consisting different forms of information and applications. Our framework suggests that the party's e-Campaign consists of five practices: information dissemination, voter interaction/engagement, support mobilisation, targeting campaigns and resource generation.

Information dissemination. This practice can be directly observed by: 1. CE 1 (party information); 2. CE 2 (candidate information); 3. CE 5, 6 and 7 (information about the party's and its candidates' other online presences); 4. CE 12 (speeches); 5. CE 13

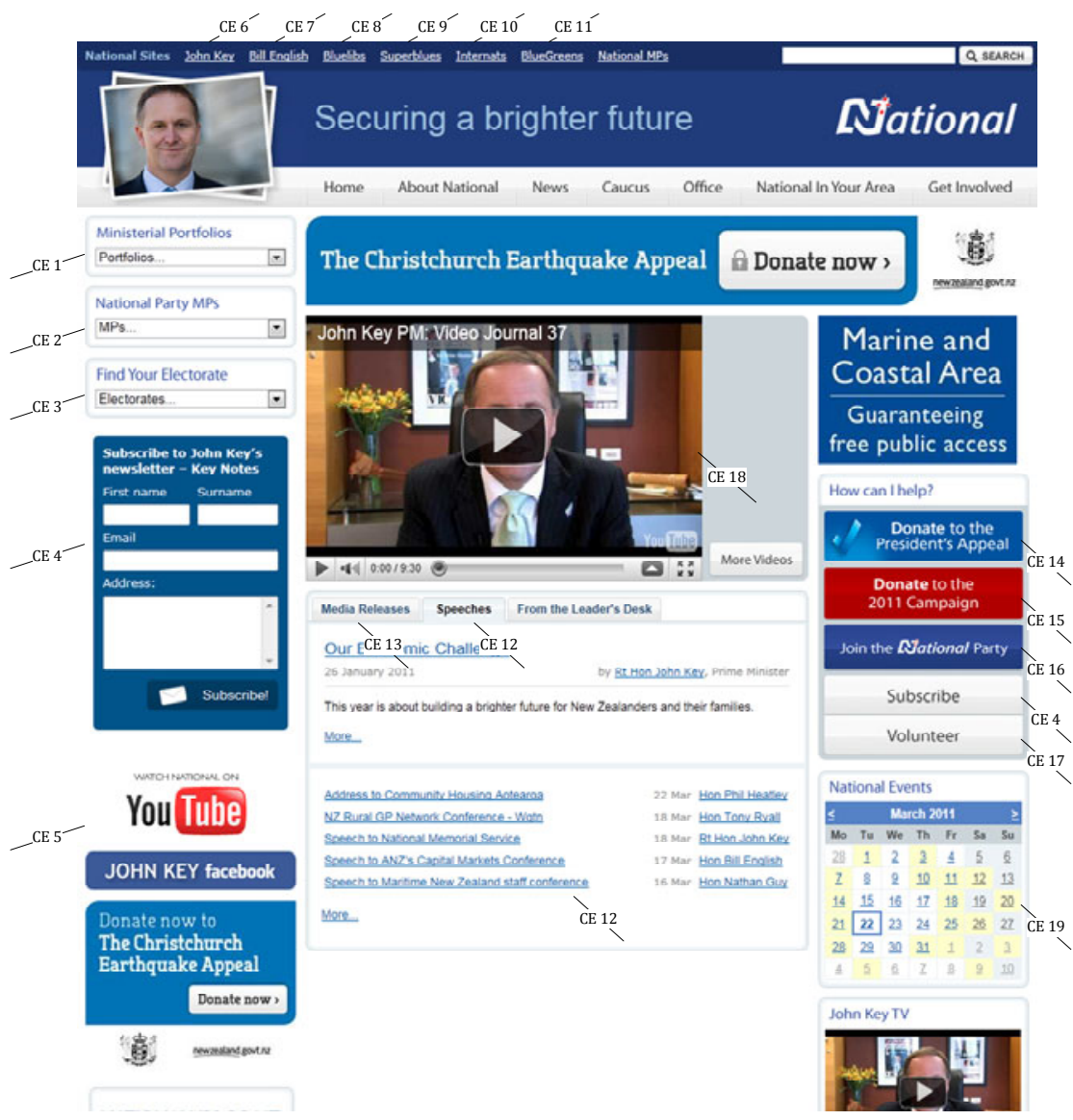

Fig. 2. The Home Page of the New Zealand National Party's 2011 e-Campaign 
(press releases); and 6. CE 18 (campaign blogs without visitor comments allowed). Voter interaction/engagement. This practice is reflected in CE 19 (interactive calendar of campaign events). Support mobilisation. This practice is operationalised in: 1. CE 3 (means to inform voters of electoral information); and 2. CE 4 (means to receive campaign information and updates). Targeting campaigns. This practice can be found in CE 8, 9, 10 and 11 (campaign targeting specific voter strata). Resource generation. This practice can be seen in: 1. CE 14 and 15 (means to make donations); 2. CE 16 (means to become a party member); and 3. CE 17 (means to become a volunteer).

The preliminary analysis indicates that National's e-Campaign encompasses all five e-Campaigning practices, with a particular focus on information dissemination and resource generation. We can also observe that a variety of different technologies are used to enable different content elements within the same e-campaigning practice. For example, information dissemination utilises drop-down boxes for CE 1 and 2 (to enable the viewer to select the information of most interest to them), links to social media (CE 5) and hyper-links to speeches and media releases (CE 12 and 13). We can see that different media can be used to enable the same practice, conversely, similar media (for example click-through links as shown in CE's 4, 14, 15, 16 and 17) can be used to enable different practices. This suggests that a practice-based framework will provide a more robust, and extensible basis for evaluating and comparing e-Campaigning practices than frameworks with a technologically deterministic orientation.

\section{Conclusion}

With an increasing uptake of new media in countries around the world and an institutional requirement for governments to organise election campaigns on a regular basis, it is clear that e-Campaigning practices will continue to be an important research topic for scholars working in the broader field of e-Participation. Consequently, having a comprehensive and robust analytical framework for understanding and explaining e-Campaigning practices over time and independent of the utilisation of specific technologies is a necessary condition for the development of theory and knowledge in this emerging research field. Thus far however, existing frameworks used for the study of e-Campaigning practices vary in the forms and types of e-Campaigning practices they cover and strongly focus on available technology to date.

Drawing from political science literature, this paper aims to close these gaps by proposing a comprehensive analytical framework that puts the purposes of election campaigning back into e-Campaigning research. Further research will be needed to test the application of the proposed framework in a variety of political election campaigns and with the availability of new technologies over time.

\section{References}

1. Farrell, D.M., Schmitt-Beck, R.: Do political campaigns matter? In: Campaign Effects in Elections and Referendums. Routledge, London (2002)

2. Bentivegna, S.: Italy: The evolution of e-Campaigning 1996-2006. In: Ward, S., Owen, D., Davis, R., Taras, D. (eds.) Making a Difference: A Comparative View of the Role of the Internet in Election Politics, pp. 217-234. Lexington Books, Plymouth (2008) 
3. Schweitzer, E.J.: Innovation or normalization in e-Campaigning?: A longitudinal content and structural analysis of German party websites in the 2002 and 2005 national elections. European Journal of Communication 23(4), 449-470 (2008)

4. Dougherty, M., Foot, K.A.: The Internet and elections project research design. In: Kluver, R., Jankowski, N., Foot, K., Schneider, S. (eds.) The Internet and National Elections, pp. 16-26. Routledge, London (2007)

5. Gibson, R., McAllister, I.: Australia: Potential Unfulfilled? The 2004 election online. In: Ward, S., Owen, D., Davis, R., Taras, D. (eds.) Making a Difference: A Comparative View of the Role of the Internet in Election Politics, pp. 35-56. Lexington Books, Plymouth (2008)

6. Ward, S., Gibson, R., Lusoli, W.: The United Kingdom: Parties and the 2005 virtual election campaign - Not quite normal? In: Ward, S., Owen, D., Davis, R., Taras, D. (eds.) Making a Difference: A Comparative View of the Role of the Internet in Election Politics, pp. 133-160. Lexington Books, Plymouth (2008)

7. Voerman, G., Boogers, M.: The Netherlands: Digital campaigning in the 2002 and 2003 parliamentary elections. In: Ward, S., Owen, D., Davis, R., Taras, D. (eds.) Making a Difference: A Comparative View of the Role of the Internet in Election Politics, pp. 197215. Lexington Books, Plymouth (2008)

8. Foot, K.A., Schneider, S.M.: Web campaigning. The MIT Press, London (2006)

9. Gibson, R.: Web campaigning from a global perspective. Asia-Pacific Review 11(1), 95126 (2004)

10. Ward, S., Owen, D., Davis, R., Taras, D.: Making a difference: A comparative view of the role of the Internet in election politics. Lexington Books, Plymouth (2008)

11. Margolis, M., Moreno-Riano, G.: The prospect of Internet democracy. Ashgate Publishing Limited, Surrey (2009)

12. Dubin, R.: Theory building. Free Press, London (1978)

13. Lilleker, D.G., Jackson, N., http://newpolcom.rhul.ac.uk/politics-web20-paper-

download/Lilleker\%20\%20Jackson\%2 0Web\%202\%200\%202008.pdf

14. The Bivings Group.: The Internet's role in political campaigns. Report, The Bivings Group (2006)

15. Gibson, R., Nixon, R., Ward, S.: Political parties and the Internet: Net gain? Routledge, London (2003)

16. Dader, J.-L.: Spain: Cyber-quake in a soft democracy? The role of the Internet in the 2004 general elections. In: Ward, S., Owen, D., Davis, R., Taras, D. (eds.) Making a Difference: A Comparative View of the Role of the Internet in Election Politics, pp. 101-106. Lexington Books, Plymouth (2008)

17. Hill, D.: Indonesia: Electoral politics and the Internet. In: Ward, S., Owen, D., Davis, R., Taras, D. (eds.) Making a Difference: A Comparative View of the Role of the Internet in Election Politics, pp. 75-92. Lexington Books, Plymouth (2008)

18. Schweitzer, E.J.: Germany: Online campaign professionalism in the 2002 and 2005 national elections. In: Ward, S., Owen, D., Davis, R., Taras, D. (eds.) Making a Difference: A Comparative View of the Role of the Internet in Election Politics, pp. 235255. Lexington Books, Plymouth (2008)

19. Davenport, T.H., Eccles, R.G., Prusak, L.: Information politics. MIT Sloan Management Review 34(1), 53-65 (1992)

20. Owen, D., Davis, R.: United States: Internet and elections. In: Ward, S., Owen, D., Davis, R., Taras, D. (eds.) Making a Difference: A Comparative View of the Role of the Internet in Election Politics, pp. 93-112. Lexington Books, Plymouth (2008) 
21. Anstead, N.: The Internet and campaign finance in the US and the UK: An institutional comparison. Journal of Information Technology \& Politics 5(3), 285-302 (2008)

22. Hill, S.: World wide webbed: The Obama campaign's masterful use of the Internet. Social Europe Journal 4(2), 9-15 (2009)

23. Schmitt-Beck, R.: Political communication effects: The impact of mass media and personal conversations on voting. In: Esser, F., Pfetsch, B. (eds.) Comparing Political Communication: Theories, Cases, and Challenges, pp. 293-324. Cambridge University Press, Cambridge (2004)

24. McAllister, I.: Calculating or capricious? The new politics of late deciding voters. In: Farrell, D.M., Schmitt-Beck, R. (eds.) Do Political Campaigns Matter? Campaign Effects in Elections and Referendums, pp. 22-40. Routledge, London (2002)

25. Foot, K.A., Schneider, S.M., Dougherty, M.: Online structure for political action in the 2004 U.S. congressional electoral web sphere. In: Kluver, R., Jankowski, N., Foot, K., Schneider, S. (eds.) The Internet and National Elections, pp. 92-104. Routledge, London (2007)

26. Norris, P.: Digital divide?: Civic engagement, information poverty, and the Internet worldwide. Cambridge University Press, Cambridge (2001)

27. Gallaugher, J., Ransbotham, S.: Social media and customer dialog management at Starbucks. MIS Quarterly Executive 9(4), 197-212 (2010)

28. Margolis, M., Resnick, D., Levy, J.: Major parties dominate, minor parties struggle: US elections and the Internet. In: Gibson, R., Nixon, R., Ward, S. (eds.) Political Parties and the Internet: Net gain?, pp. 53-69. Routledge, London (2003) 